\title{
KONVERSI KALENDER DARI HIJRIYAH KE MASEHI
}

\author{
Marwadi*
}

\section{Abstract}

A method to define the first day of Qomariyah or Hijriyah months is by rukyatul bilal. It will be esmore perfect when it uses a contemporary bisab method. The data from contemporary hisab sourc (Ephemis and Nautical almanac) are in Masehi calendar system. To find out data for doing the bisab we have to convert from Hijriyah calendar to Masebi calendar.

Kata kunci: Konversi Kalender, Kalender Hijriyah, Kalender Masebi.

\section{A. Pendahuluan}

Kemajuan ilmu pengetahuaan dan teknologi saat ini sudah sedemikian pesatnya, termasuk dalam bidang astronomi. Dengan menggunakan teknik perhitungan dan data astronomis yang mutakhir posisi benda-benda langit terutama bulan, setiap saat sudah dapat diketahui orang, sebab ternyata orang sudah mampu mencari dan menemukan serta mendarat di bulan tersebut di angkasa luar. Jadi setiap saat posisi bulan itu sudah dapat diketahui orang. Pada tanggal dan jam tertentu, bulan berada pada posisi tertentu terhadap bumi, Syariah.

- Penulis adalah Magister Hukum Islam dan Dosen tetap STAIN Purwokerto Jurusan 
matahari dan benda-benda langit lainnya. Dengan kata lain dengan menggunakan teknik perhitungan dan data astronomi yang mutakhir orang sudah dapat mengetahui bahwa pada tanggal dan jam tertentu bulan telah mempunyai ketinggian tertentu bila dilihat dari tempat tertentu di bumi ini.

Dalam era kemajuan ilmu pengetahuan dan teknologi yang demikian, masih relevankah kegiatan rukyat dilakukan oleh umat Islam? Menurut Nabhan Maspoetra, paling kurang ada tiga alasan mengapa kegiatan ru'yah al-biläl pada awal bulan qamariah perlu dilaksanakan. Pertama, alasan agama, bahwa untuk berpuasa atau ber-idul fitri harus berdasarkan pada rukyat hilal, sebagaimana disabdakan oleh Rasululah saw:

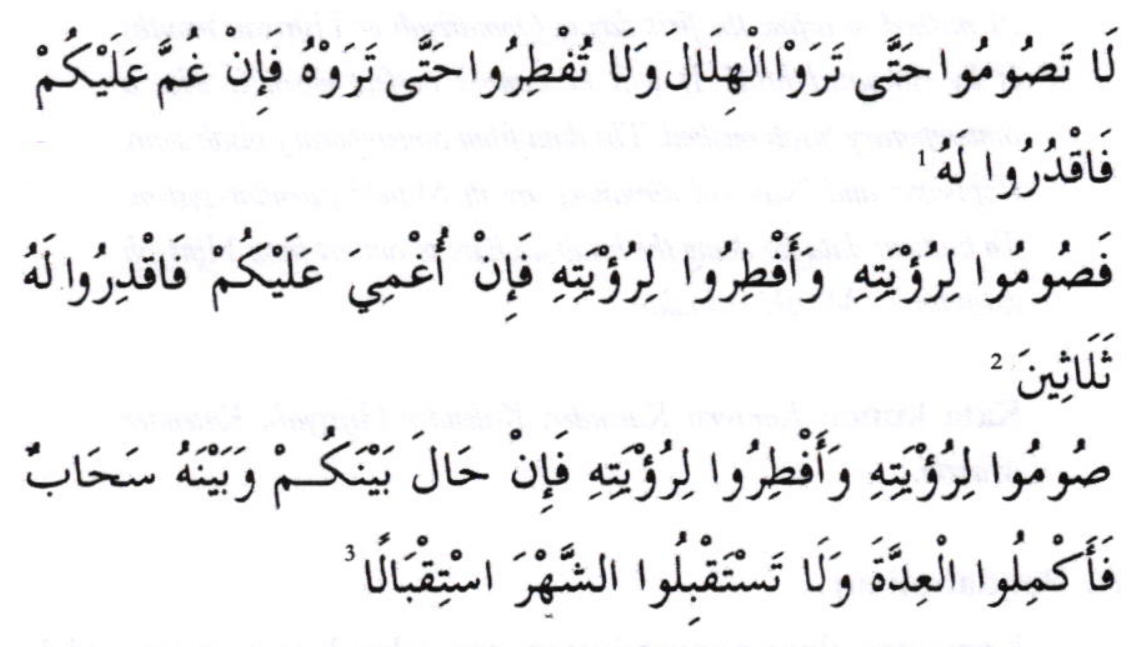

${ }^{1}$ Abu 'Abd Allah Muhammad ibn Isma'ỉ ibn Ibrahim ibn al-Mughíah ibn Bardazbah al-Bukhārí, Șaḅịh al-Bukhārì (Beirut: Dār al-Fikr, 1994), II: 229. Arti hadis tersebut adalah: "Janganlah kalian berpuasa sebelum melihat bilal dan janganlab kalian berbuka sebelum melihatnya. Maka jika ia tertutup avan bagimu, maka perkirakanlah."

${ }^{2}$ Abū al-Ḥusayn Muslim ibn al-Ḥajjaj al-Qushayrí al-Naysabữí, Șahịh Muslim (Indonesia: Dār Ihya ${ }^{7}$ al-Kutub, tt.), I: 436. "Berpuasalab kalian karena melihat bilal dan berbukalah karena melibatnya. Jika tertutup awan maka sempurnakan (bilangan bulan Sya'ban) tiga pulub hari."

${ }^{3} \mathrm{Abu}$ 'Abd al-Rahmān Ah\}mad bin Shu'ayb ibn 'Alí ibn Sinān ibn Bahr al-Khurāāní al-Nasa ${ }^{\top} \overline{1}$, Sunan al-Nasa $\hat{\imath}$ (Beirut: Dār al-Fikr, 2005), IV: 135. Arti hadis: 'Berpuasalab kalian karena melihat bilal (Ramadhan) dan berbukalab kalian karena melihat bilal (Syawal). Jika avan menghalangi antara kalian dan bilal, maka sempurnakanlah bilangan (Sya'ban). Sekali-kali janganlah mendabului bulan Ramadhan." 
Kedua, dapat disebut sebagai alasan ilmiah dalam arti bahwa ru'yah al-biläl diperlukan untuk pengembangan ilmu hisab. Seperti diketahui bahwa hasil-hasil perhitungan yang dilakukan oleh para ahlinya didasarkan pada data-data astronomis yang berbeda-beda dan lokasi pengambilan data yang berbeda-beda pula. Untuk kepentingan pengembangan ilmu hisab, tentunya hasil-hasil perhitungan tersebut perlu diuji sampai di mana akurasinya. Bila ternyata akurasi suatu sistem hisab telah berkurang, kiranya perlu dilakukan penyesuaian atau peninjauan kembali terhadap data yang mendasarinya. Bila hisab dipandang sebagai ilmu yaitu bagian dari ilmu astronomi, kiranya harus sanggup diuji secara empiris. Bila hasilhasil perhitungan tersebut tidak dapat diuji atau belum pernah diuji secara empiris, kiranya akan mengurangi kadar ilmiahnya. Seperti diketahui posisi benda-benda langit itu selalu berubah dari waktu ke waktu, sedangkan data astronomis yang terdapat dalam kitabkitab hisab itu tetap. Kalau data itu tidak pernah diuji dan disesuaikan secara empiris, tentu deviasi antara hasil-hasil perhitungan tersebut dengan keadaan sebenarnya di lapangan semakin lama akan semakin melebar. Hal ini kiranya perlu disadari oleh para ahli hisab.

Ketiga, bila kegiatan ru'yah al-biläl dapat dilakukan secara teratur dan hasil-hasilnya dihimpun dan disusun dengan baik, hal itu akan semakin membantu para ahli baik hisab maupun rukyat, dalam menentukan kadar imkän al-ru'yah al-biläl pada suatu tempat dan waktu tertentu. Dalam hal ini ini kadar imkān al-rukyat pada daerah tertentu mungkin akan berbeda dengan daerah lainnya. Data hasil ru'yah al-biläl dari berbagai tempat dan waktu akan dapat dipergunakan oleh para ahli untuk mengambil kesimpulan bahwa pada ketinggian dan dengan beda azimut tertentu antara bulan dan matahari, hilal belum mungkin untuk dapat dirukyat. ${ }^{4}$

Untuk dapat melakukan rukyat dengan baik, maka terlebih dahulu harus dilakukan hisab atau perhitungan tentang posisi hilal

\footnotetext{
${ }^{4}$ Nabhan Maspoetra, "Dari Buku Ephemeris Hisab Rukyat, Hisab Dengan Data” dalam Choirul Fuad Yusuf dan Bashori A. Hakim (Ed.), Hisab Rukyat dan Perbedaannya (Jakarta: Departemen Agama RI, 2004), hal.182-183.
} 


\section{Marwadi}

baik ketinggian maupun azimutnya pada saat matahari terbenam tanggal 29 bulan Qamariyah atau Hijriyah, dengan menggunakan koordinat geografis tempat di mana rukyat akan dilaksanakan. Proses perhitungan posisi hilal pada saat matahari terbenam pada tanggal 29 bulan Qamariah itu dikenal dengan istilah hisab hakiki yaitu perhitungan awal bulan Qamariyah yang didasarkan pada posisi bulan yang sesungguhnya dalam peredarannya di angkasa di lihat dari bumi. $^{5}$

Hisab hakiki dibedakan antara hisab hakiki taqríbi, hakiki tabqiqi $i$, serta hisab kontemporer yaitu hisab yang bersumber dari data-data astronomi kontemporer. Hisab hakiki taqrībỉ dan hakiki tabqiqi misalnya Sullam al-Nayyirayn, Qawä'id Falakiyyah, Faț al-Ra'îf al-Mannän, Badi' ab al-Mithäl, Khulāsah al-Wafiyyah, Mațla' al-Sa'id dan Hisāb Haqiqi. Sedangkan hisab hakiki kontemporer misalnya dari Newcomb, Ephemeris, Almanak Nautika dan Jean Meeus. ${ }^{6}$ Hisab kontemporer banyak dipakai oleh mayoritas ahli hisab rukyat karena diyakini mempunyai ketelitian yang tinggi. ${ }^{7}$ Namun karena data-data yang dimuat dalam Newcomb, Ephemeris, Almanak Nautika dan Jean Meeus adalah menurut kalender Masehi, sedangkan posisi hilal yang akan dihitung adalah tanggal 29 bulan Qamariah/Hijriyah, maka sebelum melakukan hisab harus menkonversi dahulu tanggal 29 bulan Qamariah tersebut ke dalam kalender Masehi. ${ }^{8}$ Tulisan ini bermaksud menguraikan kalender Hijriyah, kalender Masehi dan bagaimana proses perhitungan konversi kalender dari kalender Hijriyah ke dalam kalender Masehi.

\footnotetext{
${ }^{5}$ Departemen Agama RI, Pedoman Perbitungan Awal Bulan Qamariyab (Jakarta: Bagian Proyek Pembinaan Administrasi Hukum dan Peradilan Agama, 1983), hal. 8. bandingkan idem, Almanak Hisab Rukyat (Jakarta: Proyek Pembinaan Badan Peradilan Agama Islam, 1981), hal. 83.

${ }^{6}$ Susiknan Azhari, Hisab dan Rukyat: Wacana Untuk Membangun kebersamaan di Tengab Perbedaan (Yogyakarta: Pustaka Pelajar, 2007), hal. 4. Abd. Salam Nawawi, Rukyat Hisab di Kalangan NU Mubammadiyah (Surabaya: Diantama, 2004), hal. 10-11.

${ }^{7}$ S. Farid Ruskanda, 100 Masalab Hisab \&r Rukyat: Telaab Syari'ab, Sains dan Teknologi (Jakarta: Gema Insani Press, 1996), hal.16.

${ }^{8}$ Muhyiddin Khazin, Ilmu Falak Dalam Teori dan Praktek (Yogyakarta: Buana Pustaka, 2004), hal. 122.
} 


\section{B. Kalender Hijriyah}

Kalender Hijriyah dikenal pula dengan kalender Qamariyah yaitu sistem perhitungan waktu berdasarkan pada perjalanan bulan terhadap bumi. ${ }^{9}$ Perhitungan tahun Hijriyah sebenarnya pernah digunakan oleh Rasululah saw ketika beliau menulis surat kepada kaum Nasrani Bani Najran, tertulis tahun ke-5 Hijriyah. Namun di dunia Arab pada waktu itu umumnya lebih mengenal peristiwaperistiwa yang terjadi pada tahun tersebut, kemudian dipakai sebagai nama tahun dimaksud seperti tahun Gajah, tahun Izin, tahun Amar dan tahun Zilzal. Nama-nama tahun tersebut diidentikkan dengan peristiwa-peristiwa yang terjadi pada masa itu. ${ }^{10}$

Menurut sejarah, kalender Hijriyah ini dimulai sejak Umar bin Khaththab 2.5 tahun diangkat sebagai khalifah, yaitu sejak terdapat persoalan yang menyangkut sebuah dokumen yang terjadi pada bulan Sya'ban. Muncullah pertanyaaan bulan Sya'ban yang mana? Oleh sebab itu Umar bin Khathtab memanggil beberapa orang sahabat terkemuka guna membahas persoalan tersebut. Agar persoalan semacam itu tidak terulang lagi maka diciptakanlah penanggalan Hijriyah. Atas usul Ali bin Abi Thalib maka penanggalan Hijriyah dihitung mulai tahun yang di dalamnya terjadi Hijriyah Nabi Muhammad SAW dari Makah ke Madinah. Dengan demikian penanggalan Hijriyah itu diberlakukan mundur sebanyak 17 tahun.

Tanggal 1 Muharram tahun 1 Hijriyah ada yang berpendapat jatuh pada hari Kamis tanggal 15 Juli 622 M. Penetapan ini kalau berdasarkan pada hisab, sebab irtifa' hilal pada hari Rabu 14 Juli 622 M sewaktu matahari terbenam sudah mencapai 5 derajat 57 menit. Pendapat lain mengatakan 1 Muharram 1 Hijriyah jatuh pada haru Jum'at tanggal 16 Juli $622 \mathrm{M}$. Ini apabila permulaan bulan didasarkan pada rukyah, karena sekalipun posisi hilal pada menjelang 1 Muharram 1 Hijriyah sudah cukup tinggi, namun waktu itu tidak satupun didapati laporan hasil rukyah.

9 Susiknan Azhari, Ensiklopedi Hisab Rukyat (Yogyakarta: Pustaka Pelajar, 2004), hal. 88.

${ }^{10}$ Sofwan Jannah, Kalender Hijriyah dan Masebi 150 Tabun (Yogyakarta: UII Press, 1994), hal. 2. 
Penanggalan Hijriyah ini berdasarkan pada peredaran bulan mengelilingi bumi. Satu kali edar lamanya 29 hari 12 jam 44 menit 2,5 detik. Untuk menghindari adanya pecahan hari maka ditentukan bahwa umur bulan ada yang 30 hari dan adapula yang 29 hari, yaitu untuk bulan-bulan ganjil berumur 30 hari, sedang bulan-bulan genap berumur 29 hari, kecuali pada bulan ke 12 (Dzulhijjah) pada tahun Kabisat berumur 30 hari. Setiap 30 tahun terdapat 11 tahun Kabisat (panjang $=$ berumur 355 hari) dan 19 tahun Basithah (pendek = berumur 354 hari). Tahun-tahun Kabisat jatuh pada urutan ke 2, 5, $7,10,13,15,18,21,24,26,29$, Sedangkan selain urutan tersebut merupakan tahun Basithah. ${ }^{11}$

Ketentuan yang demikian itu kadangkala tidak sama dengan penampakan hilal sesaat setelah matahari terbenam pada hari ke 29 bulan hijriyah. Padahal nabi Muhammad saw telah memberikan petunjuk bahwa untuk penentuan awal bulan qamariyah atau hijriyah, khususnya untuk memulai puasa Ramadhan atau mengakhirinya adalah dengan penampakan hilal. Kalau pada hari ke 29 itu ada laporan penampakan hilal maka malam itu atau keseokan harinya merupakan tanggal satu bulan berikutnya, tetapi kalau pada hari itu tidak didapati laporan penampakan hilal maka malam itu dan keesokan harinya masih merupakan hari ke 30 bulan yang sedang berlangsung. Oleh karena itu tidaklah berlebihan apabila untuk pembuatan kalender hijriyah hendaknya memadukan antara nas dan akal, yakni tetap memperhatikan petunjuk Rasulullah saw yang dipadukan dengan ilmu pengetahuan hisab. ${ }^{12}$

Kalender Hijriyah mempunyai ketentuan; (a) satu tahun ada 12 bulan, yaitu Muharram, Shafar, Rabi'ul Awal, Rabi'ul Akhir, Jumadil Ula, Jumadil Akhirah, Rajab, Sya'ban, Ramadhan, Syawwal, Dzulqa'dah dan Dzulhijjah. (b) 1 tahun Hijriyah $=354$ hari (Basithah), Dzulhijjah $=29$ hari $=355$ hari (Kabisat), Dzulhijjah $=$

${ }^{11}$ Muhyiddin Khazin, Ilmu Falak, hal. 112-113. Abu Yusuf al-Atsary, Pilib HisabRu'yah (Solo: Pustaka Darul Muslim, Tt), hal.39-42.

${ }^{12}$ Muhyiddin Khazin, 150 Tahun Kalender Masebi-Hijrijah (Jakarta: Direktorat Urusan Agama Islam dan Pembinaan Syari'ah Departemen Agama RI, 2007), hal. xx. 
30 hari. (c) Tahun-tahun Kabisat jatuh pada urutan tahun ke 2, 5, 7, $10,13,15,18,21,24,26$, dan 29 (tiap 30 tahun), (d) 1 daur $=30$ tahun $=10631$ hari. $^{13}$

\section{Kalender Masehi}

Kalender Masehi dikenal pula dengan kalender Syamsiyah atau kalender Miladiyah yaitu sistem perhitungan waktu yang berdasarkan pada pergerakan relatif bumi terhadap matahari. ${ }^{14}$ Kaleder Masehi atau Miladi diciptakan dan diproklamirkan penggunaannya oleh Numa Pompilus pada tahun berdirinya kerajaan Roma tahun 753 SM. Penanggalan ini berdasarkan pada perubahan musim sebagai akibat peredaran semu matahari, dengan menetapkan panjang satu tahun berumur 366 hari. Bulan pertamanya adalah Maret, karena posisi matahari berada di titik Aries itu terjadi pada bulan Maret.

Kemudian pada tahun 46 SM, menurut penanggalan Numa sudah bulan Juni, tetapi posisi matahari sebenarnya baru pada bulan Maret sehingga oleh Yulius Caesar, penguasa Romawi, atas saran dari ahli astronomi Iskandaria yang bernama Sosigenes diperintahkan agar penanggalan Numa tersebut diubah dan disesuaikan dengan posisi matahari yang sebenarnya, yaitu dengan memotong penanggalan yang sedang berjalan sebanyak 90 hari dan menetapkan pedoman baru bahwa satu tahun itu ada 365.25 hari. Bilangan tahun yang tidak habis dibagi empat sebagai tahun pendek (Basithah) berumur 365 hari, sedangkan bilangan tahun yang habis dibagi empat adalah tahun panjang (Kabisat) berumur 366 hari. Selisih satu hari ini diberikan pada urutan bulan yang terakhir (waktu itu), yakni bulan Pebruari. Penanggalan hasil koreksian ini kemudian dikenal dengan Kalender Yulias atau Kalender Yulian. ${ }^{15}$

Baru kemudian pada waktu Dewan Yustisi Gereja bersidang yang pertama kalinya pada bulan Januari $525 \mathrm{M}$, atas saran Dyonsius Exiquus maka mulai saat itu bulan Januari ditetapkan sebagai bulan

\footnotetext{
${ }^{13}$ Idem, Ilmu Falak, hal. 113.

${ }^{14}$ Azhari, Ensiklopedi, hal. 88.

${ }^{15}$ Khazin, Ilmu Falak..., hal. 105-106.
} 
yang pertama sedangkan bulan yang terakhir adalah Desember. Disamping itu ditetapkan pula bahwa tahun kelahiran isa al-Masih dijadikan sebagai tahun pertama. Sistem ini dikenal dengan nama sistem Yustinian. Meskipun sudah diadakan koreksi dan perubahan, namun ternyata kalender Yulian masih lebih panjang 11 menit 14 detik dari titik musim yang sebenarnya, sehingga sebagai akibatnya kalender itu harus mundur 3 hari setiap 400 tahun. ${ }^{16}$

Pada tahun 1582 ada hal yang menarik perhatian, yaitu saat penentuan wafat Isa al-Masih, yang diyakini oleh orang-orang Masehi bahwa peristiwa itu jatuh pada hari Minggu setelah bulan purnama yang selalu terjadi segera setelah matahari di titik Aries (tanggal 21 Maret). Tetapi pada waktu itu mereka memperingatinya tidak lagi pada hari Minggu setelah bulan purnama setelah matahari di titik Aries, namun sudah beberapa hari berlalu. Hal demikian ini mengetuk hati Paus Gregorius XIII untuk mengadakan koreksi terhadap sistem penanggalan Yustinian yang sudah berlaku agar sesuai dengan posisi matahari yang sebenarnya.

Atas saran Klafius (ahli perbintangan), pada tanggal 4 Oktober 1582 Paus Gregorius XIII memerintahkan agar keesokan harinya tidak dibaca 5 Oktober 1582, melainkan dibaca 15 Oktober 1582 dan ditetapkan bahwa peredaran matahari dalam satu tahun itu 365.2425 hari, sehingga ada ketentuan baru, yaitu angka tahun yang tidak habis dibagi 400 atau angka abad yang tidak habis dibagi 4 adalah tahun Basithah (365 hari). Serta ditetapkan bahwa tahun kelahiran Isa al-Masih dijadikan sebagai tahun pertama. Dengan demikian setiap 4 tahun merupakan satu siklus (1461 hari). Sistem penanggalan ini dikenal dengan Sistem Gregorian. Sistem Gregorian inilah yang berlaku sampai sekarang ini.

Kaleder Masehi mempunyai ketentuan sebagai berikut: ${ }^{17}$

1. Setiap tahun ada 12 bulan, yaitu Januari, Pebruari, Maret, April, Mei, Juni, Juli, Agustus, September, Oktober, November,

\footnotetext{
${ }^{16}$ Khazin, 150 Tabun, hal. xvii.

${ }^{17}$ Idem, Ilmu Falak, hal. 107.
} 
Desember. Bulan ke 1, 3, 5, 7, 8, 10 dan 12 masing-masing berumur 31 hari, sedang lainnya berumur 30 hari, kecuali bulan ke 2 (Pebruari) berumur 28 hari pada tahun Basithah (pendek) dan berumur 29 hari pada tahun Kabisat (panjang).

2. 1 tahun Masehi $=365$ hari $($ Basithah $)$, Pebuari $=28$ hari atau 366 hari (Kabisat), Pebuari $=29$ hari.

3. Tahun Kabisat adalah bilangan tahun yang habis dibagi 4 (mis. 1992, 1996, 2000, 2004), kecuali bilangan abad yang tidak habis dibagi 4 (mis. 1700, 1800, 1900, 2100 dst), selain itu adalah Basithah.

4. 1 siklus $=4$ tahun (1461 hari). (e) Penyesuaian akibat anggaran Gregorius sebanyak 10 hari sejak 15 Oktober 1582 SM, serta penambahan 1 hari pada setiap bilangan abad yang tidak habis dibagi 4 sejak tanggal tersebut, sehingga sejak tahun 1900 sampai 2099 ada penambahan koreksi 13 hari $(10+3)$.

\section{Konversi Kalender Hijriyah ke Kalender Masehi}

Konversi kalender dikenal pula dengan istilah perbandingan tarikh atau tậuil al-sanah yaitu persamaan tanggal antara dua sistem kalender atau penanggalan. ${ }^{18}$ Metode operasional konversi kalender Hijriyah ke dalam kalender Masehi melalui tahapan-tahapan sebagai berikut:

1. Menentukan jumlah hari dari tanggal 1 Muharram 1 Hijriyah hingga tanggal yang akan dicari konversinya. ${ }^{19}$ Misalnya jika akan melakukan konversi kalender antara tanggal 29 Ramadhan 1429 $\mathrm{H}$, dengan tanggal menurut kalender Masehi, maka jumlah hari yang dicari adalah jumlah hari mulai tanggal 1 Muharram $1 \mathrm{H}$ sampai dengan tanggal 29 Ramadhan $1429 \mathrm{H}$. Hal ini dapat dilakukan dengan cara:

a. Menghitung tahun täm yakni tahun yang akan dikonversi dikurangi satu.

${ }^{18}$ Khazin, Kamus Ilmu Falak (Yogyakarta: Buana Pustaka, 2005), hal. 80.

${ }^{19}$ Oman Fathurrahman, Diktat Kuliab Ilmu Falak II (Yogyakarta: Tnp, 1996), hal. 2. 
b. Menghitung berapa daur selama tahun tam tersebut yakni tahun täm dibagi 30.

c. Menghitung berapa tahun kelebihan dari sejumlah daur tersebut.

d. Menghitung berapa hari selama daur yang ada yakni daur dikalikan 10631 hari.

e. Menghitung berapa hari selama tahun kelebihan.

f. Menghitung berapa hari selama bulan kelebihan.

g. Menjumlahkan hari-hari tersebut.

2. Melakukan penambahan antara jumlah hari yang diperoleh pada tahap pertama dengan jumlah selisih hari antara kalender Masehi dengan kalender Hijriyah sebanyak 227.016 hari. ${ }^{20}$ Jumlah hari ini diperoleh dengan cara:

$$
\begin{array}{ll}
621: 4=155 \text { daur }+1 \text { tahun } & \\
155 \text { daur }=155 \times 1461 & =226455 \text { hari } \\
1 \text { tahun }=1 \times 365 \text { hari } & =365 \text { hari } \\
1 \text { Jan } 622 \text { M. s } / \text { d } 15 \text { Jul } 622 \text { M. } & =196 \text { hari }+ \\
\text { Jumlah } & =227016 \text { hari }
\end{array}
$$

3. Melakukan penambahan dengan koreksi Gregorius sebanyak 13 hari.

4. Mengolah hasil yang diperoleh sampai dengan tahap 3 tersebut menjadi tanggal, bulan dan tahun menurut sistem kalender Masehi. ${ }^{21} \mathrm{Hal}$ ini dapat dilakukan dengan cara:

a. Menghitung berapa siklus dengan cara jumlah hari yang diperoleh dibagi 1461.

b. Menghitung berapa tahun, dengan cara siklus dikalikan 4 .

c. Menghitung berapa tahun, dengan cara sisa hari dibagi 365 .

\footnotetext{
${ }^{20}$ Ibid., hal. 9-13.

${ }^{21}$ Ibid., hal. 15.
} 
d. Menghitung ada berapa bulan dalam kelebihan hari dan masih berapa sisa lagi.

5. Penyimpulan, yakni menyatakan tanggal, bulan dan tahun baik menurut sistem kalender yang tanggalnya sudah diketahui sejak sebelum melakukan perhitungan maupun tanggal, bulan dan tahun menurut sistem kalender yang baru saja diketemukan melalui tahap-tahap sebelumnya. ${ }^{22}$

Perlu dicatat di sini, bahwa dalam perhitungan konversi kalender untuk kalender Masehi digunakan perhitungan menurut anggaran-anggaran kalender Yulian. Oleh karena itu, jika menghitung konversi kalender sejak 15 oktober 1582, untuk mendapatkan hasil yang sebenarnya, harus dimasukkan atau dikoreksi dengan anggarananggaran yang ditetapkan menurut sistem kalender Gregorian. Anggaran-aggaran tersebut adalah loncatan tanggal sebanyak 10 hari dan tahun-tahun abad yang tidak habis dibagi dengan empat ditetapkan sebagai tahun basițah. Setelah jumlah hari dalam kalender masehi dihitung menurut sistem kalender Yulian kemudian dikurangi sebanyak 10 hari. Berikutnya lagi dikurangi dengan jumlah hari sesuai dengan bilangan abad yang tidak habis dibagi empat yang terlewati sesudah abad ke-16. Misalnya kalau menghitung konversi kalender untuk tahun 2008 M., maka pengurangan adalah 10 hari ditambah 3 hari. Pengurangan 3 hari tersebut diperoleh dari bilangan abad yang tidak habis dibagi empat yakni sebanyak 3 abad (abad ke-17, ke-18, ke-19) masing-masing abad 1 hari.

Penentuan hari dapat diketahui melalui jumlah hari yang terdapat dalam kalender Masehi maupun Hijriyah. Jika yang digunakan jumlah hari dalam kalender Masehi, maka jumlah hari itu dibagi dengan 7 dan sisanya dihitung mulai hari Sabtu. Artinya jika bersisa 1 berarti hari Sabtu, jika bersisa 2 berarti hari Ahad dan begitu seterusnya. Sedangkan jika tidak bersisa berarti hari Jumat. Jika yang digunakan jumlah hari dalam kalender Hijriyah, maka jumlah hari

22 Ibid., hal. 19. 


\section{Marwadi}

itu dibagi dengan 7 dan sisanya dihitung mulai hari Jumat. Artinya jika bersisa 1 berarti hari Jumat, jika bersisa 2 berarti hari Sabtu dan begitu seterusnya. Sedangkan jika tidak bersisa berarti hari Kamis. Ini bagi yang berpendapat bahwa tanggal 1 Muharram 1 Hijriyah jatuh pada hari Jumat Legi bertepatan dengan tanggal 16 Juli $622 \mathrm{M}$. Sedangkan bagi yang berpendapat bahwa tanggal 1 Muharram 1 Hijriyah jatuh pada hari Kamis Kliwon bertepatan dengan tanggal 15 Juli $622 \mathrm{M}$, maka sisa 1 berarti hari Kamis, sisa 2 berarti hari Jumat dan begitu seterusnya. Jika tidak bersisa berarti hari Rabu.

Penentuan pasaran dapat diketahui melalui jumlah hari yang terdapat dalam kalender Masehi maupun kalender Hijriyah. Jika yang digunakan jumlah hari dalam kalender Masehi, maka jumlah hari dibagi dengan 5 dan sisanya dihitung mulai Kliwon. Artinya jika bersisa 1 berarti Kliwon, jika bersisa 2 berarti Legi, dan begitu seterusnya. Sedangkan jika tidak bersisa berarti Wage. Jika yang digunakan jumlah hari dalam kalender Hijriyah, maka jumlah hari itu dibagi dengan 5 dan sisanya dihitung mulai Legi. Artinya jika bersisa 1 berarti Legi, jika bersisa 2 berarti Pahing dan begitu seterusnya. Sedangkan jika tidak bersisa berarti Kliwon. Ini bagi yang berpendapat bahwa tanggal 1 Muharram 1 Hijriyah jatuh pada hari Jumat Legi bertepatan dengan tanggal 16 Juli $622 \mathrm{M}$. sedangkan bagi yang berpendapat bahwa tanggal 1 Muharram 1 Hijriyah jatuh pada hari Kamis Kliwon bertepatan dengan tanggal 15 Juli $622 \mathrm{M}$, maka sisa 1 berarti Kliwon, sisa 2 berarti Legi dan begitu seterusnya. Jika tidak bersisa berarti Wage. ${ }^{23}$

\section{E. Contoh Perhitungan Konversi Kalender Hijriyah Ke Kalender Masehi.}

Mengkonversi tanggal 29 Ramadhan 1429 Hijriyah ke dalam kalender Masehi. (1 Muharram $1 \mathrm{H}$. bertepatan dengan hari Kamis Kliwon 15 Juli 622 M.).

${ }^{23}$ Ibid., hal. 21-23. 
a. Penentuan tanggal, bulan dan tahun

1. Jumlah hari sejak 1 Muharram 1 H. s/d 29 Ramadhan 1429 $\mathrm{H}$.

1428 tahun +8 bulan +29 hari

$1428: 30=47$ daur +18 tahun

47 daur $=47 \times 10631$

$=499657$ hari

18 tahun $=18 \times 354$ hari +7 hari $^{24}=6379$ hari

8 bulan $=8 \times 29+4$ hari $^{25}=236$ hari

29 hari $=$

$=29$ hari +

Jumlah

$=506301$ hari

2. Selisih Masehi - Hijriyah

$$
=\frac{227016 \text { hari }+}{733317 \text { hari }}
$$

3. Anggaran Gregorius XIII $\equiv 13$ hari + Jumlah $=733330$ hari

4. Menentukan tanggal, bulan dan tahun Masehi: $733330: 1461=501$ daur +1369 hari

$\begin{array}{lll}501 \text { daur } & =501 \times 4 \text { tahun } & =2004 \text { tahun } \\ 1369: 365 & =3 \text { tahun }+274 \text { hari } & =3 \text { tahun } \\ 274 \text { hari } & =9 \text { bulan } & =\quad 9 \text { bulan }\end{array}$
$=29$ September $2008 \mathrm{M}$.

5. Kesimpulan:

Tanggal 29 Ramadhan $1429 \mathrm{H}$. bertepatan dengan tanggal 29 September 2008 M.

b. Penentuan hari:

$506301: 7=72328$ sisa 5, berarti hari Senin (dihitung dari Kamis)

${ }^{24}$ Penambahan 7 hari disebabkan oleh adanya 7 kali tahun kabisat, yang umurnya masing-masing 355 hari, selama 18 tahun yaitu tahun ke-2, ke-5, ke-7, ke-10, ke-13, ke-15 dan ke-18.

${ }^{25}$ Penambahan 4 hari karena dalam 8 bulan ada 4 bulan yang umurnya masing-masing 30 hari yaitu bulan ke-1, ke-3, ke-5 dan ke-7. 


\section{Marwadi}

c. Penentuan pasaran:

$506301: 5=101260$ sisa 1 , berarti Kliwon (dihitung dari Kliwon)

\section{F. Penutup}

Dari uraian di atas dapat ditarik kesimpulan bahwa kalender Hijriyah mempunyai ketentuan; (a) satu tahun ada 12 bulan, yaitu Muharram, Shafar, Rabi'ul Awal, Rabi'ul Akhir, Jumadil Ula, Jumadil Akhirah, Rajab, Sya'ban, Ramadhan, Syawwal, Dzulqa'dah dan Dzulhijjah. (b) 1 tahun Hijriyah = 354 hari (basitab), Dzulhijjah = 29 hari $=355$ hari (Kabisat), Dzulhijjah $=30$ hari. (c) Tahun-tahun Kabisat jatuh pada urutan tahun ke 2, 5, 7, 10, 13, 15, 18, 21, 24, 26, dan 29 (tiap 30 tahun), (d) 1 daur $=30$ tahun $=10631$ hari.

Kalender Masehi mempunyai ketentuan; (a) Setiap tahun ada 12 bulan, yaitu Januari, Pebruari, Maret, April, Mei, Juni, Juli, Agustus, September, Oktober, November, Desember. Bulan ke 1, 3, 5, 7, 8, 10 dan 12 masing-masing berumur 31 hari, sedang lainnya berumur 30 hari, kecuali bulan ke 2 (Pebruari) berumur 28 hari pada tahun Basithah (pendek) dan berumur 29 hari pada tahun Kabisat (panjang). (b) 1 tahun Masehi $=365$ hari (Basithah), Pebuari $=28$ hari atau 366 hari (Kabisat), Pebuari $=29$ hari. (c) Tahun Kabisat adalah bilangan tahun yang habis dibagi 4 (mis. 1992, 1996, 2000, 2004), kecuali bilangan abad yang tidak habis dibagi 4 (mis. 1700, 1800, 1900, $2100 \mathrm{dst}$ ), selain itu adalah Basithah. (d) 1 siklus $=4$ tahun (1461 hari). (e) Penyesuaian akibat anggaran Gregorius sebanyak 10 hari sejak 15 Oktober 1582 SM, serta penambahan 1 hari pada setiap bilangan abad yang tidak habis dibagi 4 sejak tanggal tersebut, sehingga sejak tahun 1900 sampai 2099 ada penambahan koreksi 13 hari $(10+3)$.

Metode operasional konversi kalender Hijriyah ke kalender Masehi melalui tahapan-tahapan; 1) menentukan jumlah hari dari tanggal 1 Muharram 1 Hijriyah hingga tanggal yang akan dicari konversinya. 2) melakukan penambahan antara jumlah hari yang 
diperoleh pada tahap pertama dengan jumlah selisih hari antara kalender Masehi-Hijriyah. 3) melakukan penambahan dengan koreksi Gregorius sebanyak 13 hari. 4) mengolah hasil yang diperolah sampai dengan tahap 3 tersebut menjadi tanggal, bulan dan tahun menurut sistem kalender Masehi. 5) penyimpulan, yakni menyatakan tanggal, bulan dan tahun baik menurut sistem kalender yang tanggalnya sudah diketahui sejak sebelum melakukan perhitungan maupun tanggal, bulan dan tahun menurut sistem kalender yang baru saja diketemukan melalui tahap-tahap sebelumnya.

\section{DAFTAR PUSTAKA}

Azhari, Susiknan. Ensiklopedi Hisab Rukyat. Yogyakarta: Pustaka Pelajar, 2004. Hisab dan Rukyat: Wacana Untuk Membangun Kebersamaan di Tengah Perbedaan, Yogyakarta: Pustaka Pelajar, 2007.

Al-Atsary, Abu Yusuf. Pilib Hisab-Ru'yah. Solo: Pustaka Dartul Muslim, t.t.

Al-Bukharī, Abu 'Abd Allah Muh\}ammad ibn Isma'il ibn Ibrahím ibn al-Mughïah ibn Bardazbah. Șaḥị̣ al-Bukbāri, 6 jilidd. Beirut: Dār al-Fikr, 1994.

Fathurrahman, Oman. Diktat Kuliah Ilmu Falak II. Yogyakarta: tnp.,1996.

Jannah, Sofwan. Kalender Hijriyah dan Masehi 150 Tabun. Yogyakarta: UII Press, 1994.

Khazin, Muhyiddin. 150 Tabun Kalender Masehi-Hijriyah. Jakarta: Direktorat Urusan Agama Islam dan Pembinaan Syari'ah Departemen Agama RI, 2007. 
. Ilmu Falak Dalam Teori dan Praktek. Yogyakarta: Buana Pustaka, 2004.

. Kamus Ilmu Falak. Yogyakarta: Buana Pustaka, 2005.

Maspoetra, Nabhan. "Dari Buku Ephemeris Hisab Rukyat, Hisab Dengan Data" dalam Choirul Fuad Yusuf dan Bashori A. Hakim (Ed), Hisab Rukyat dan Perbedaannya. Jakarta: Departemen Agama RI, 2004.

Nawawi, Abd. Salam. Rukyat Hisab di Kalangan NU Mubammadiyah. Surabaya: Diantama, 2004.

Al-Nasa'í, Abu' 'Abd al-Rahmān Ah\}mad ibn Shu'ayb ibn 'Ali ibn Sinān ibn Bah\}r al-Khurāsañ. Sunan al-Nasā̄i, 7 jilid Beirut: Dār al-Fikr, 2005.

Al-Naysabưrí, Abū al-Ḥusayn Muslim ibn al-Hajajaj al-Qushayrí. Sabịh Muslim. Indonesia: Dār Ihyya al-Kutub, t.t.

Ruskanda, S. Farid. 100 Masalab Hisab \& Rukyat: Telaab Syari'ab, Sains dan Teknologi. Jakarta: Gema Insani Press, 1996.

Departemen Agama RI. Almanak Hisab Rukyat. Jakarta: Proyek Pembinaan Badan Peradilan Agama Islam, 1981.

Pedoman Perbitungan Awal Bulan Qamariyah. Jakarta: Bagian Proyek Pembinaan Administrasi Hukum dan Peradilan Agama, 1983. 